\title{
A Partial Equilibrium Analysis of Current US Monetary Policy with a Prediction
}

\author{
Elliott Middleton \\ Elliott Middleton Research \\ Elliott.middletoniii@gmail.com
}

\begin{abstract}
A partial equilibrium analysis of US credit markets reveals that the Federal Reserve System's current mechanism for raising short-term interest rates has placed the US short-term markets in a position that is far from apparent equilibria achieved over the postwar period.
\end{abstract}

The partial equilibrium referred to is that between short rates and the ratio of the St. Louis Adjusted Monetary Base to nominal GDP. See Figure 1 below [1].

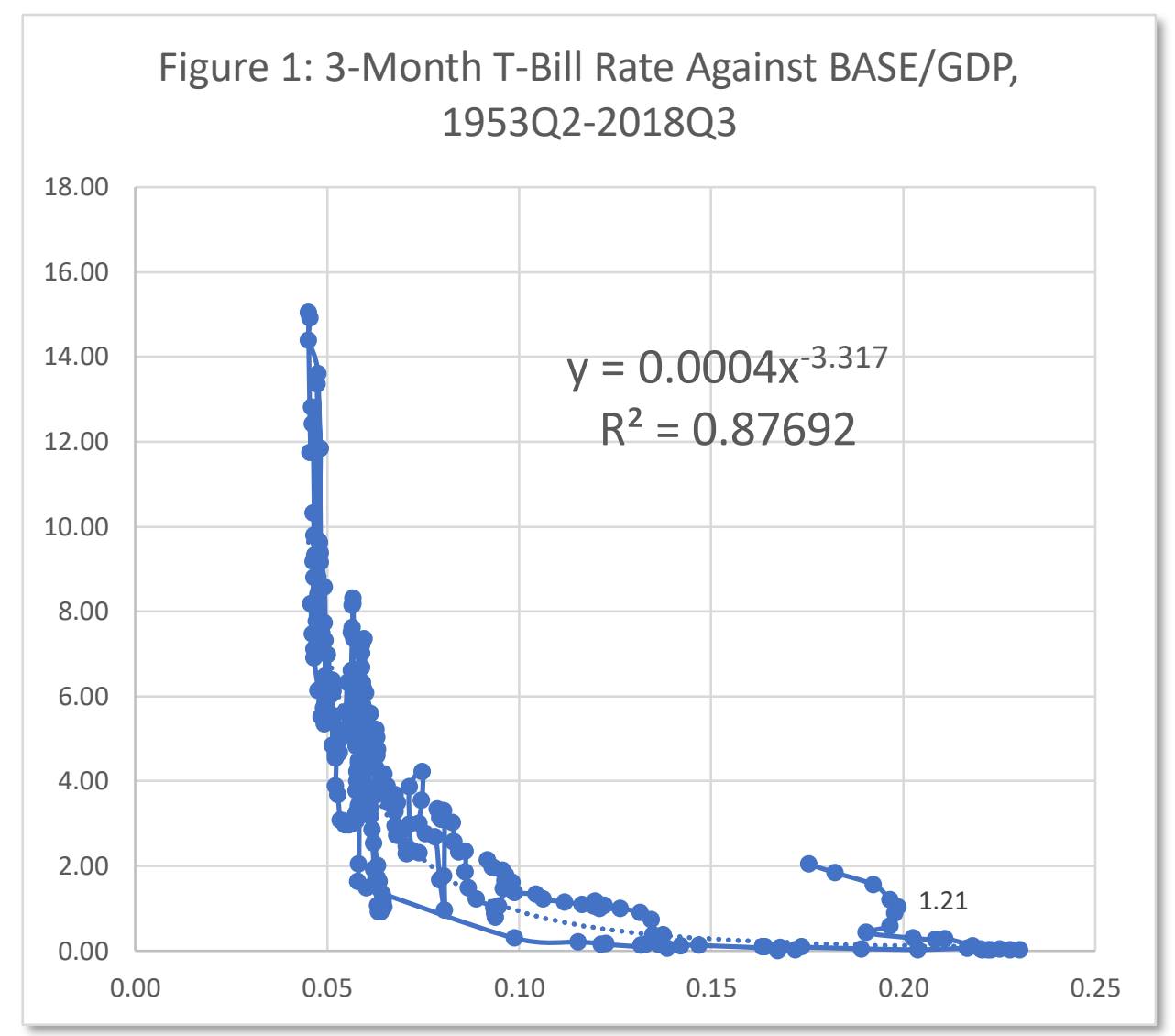

Nominal GDP flows through credit-created monetary aggregates supported by the monetary base, with higher rates of relative flow (lower ratios of base to GDP) causing the price of money to increase due to relative scarcity. This strong empirical regularity can be construed as a quasiequilibrium aggregate money demand curve. 
However, in 2015Q4 short rates began to rise anomalously with the Fed's new policy. See Figure 2 below for a close-up of the recent period.

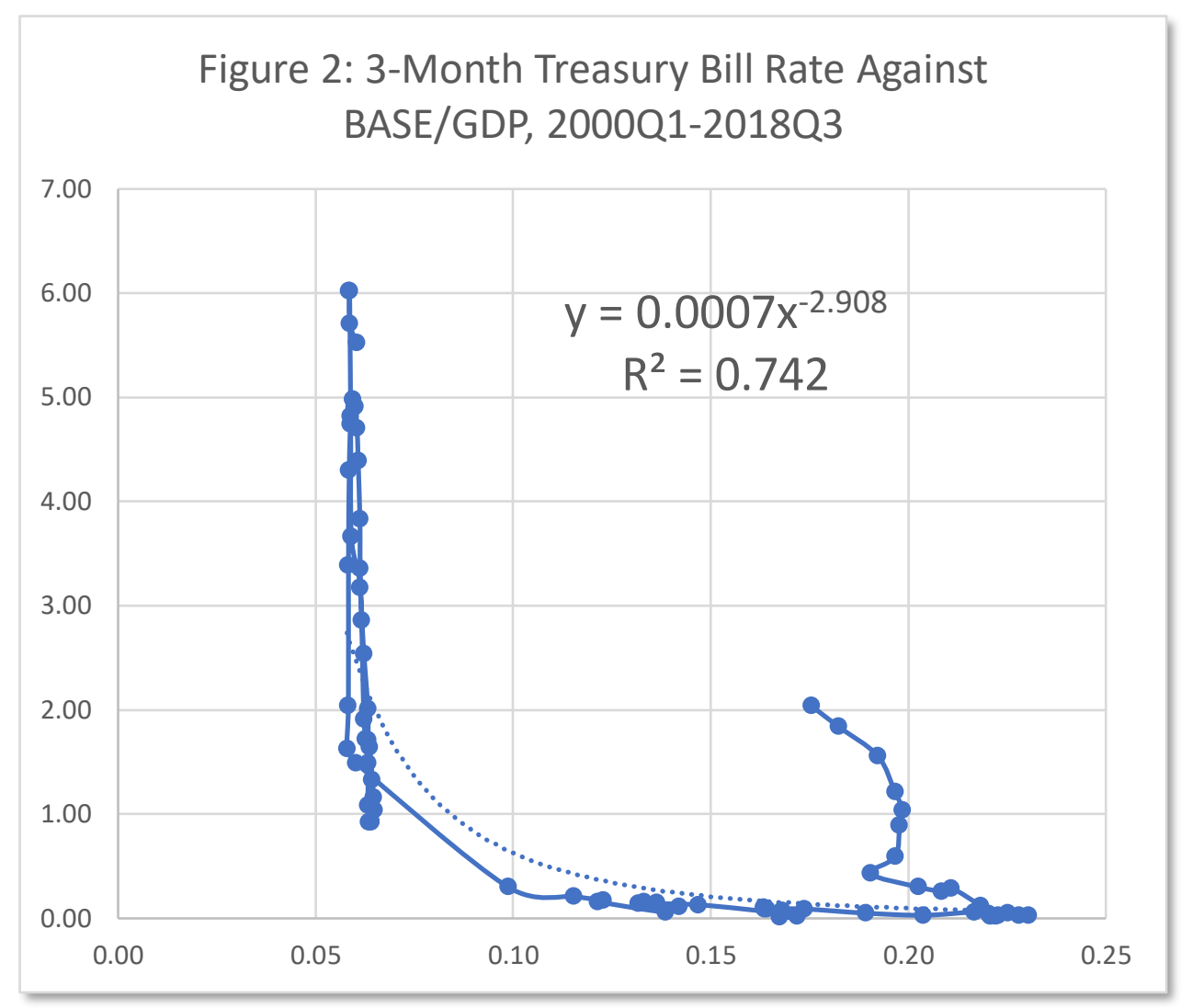

The mechanism used to implement recent interest rate increases has been to pay banks interest on excess reserves, an innovation dating from the Global Financial Crisis pressed into heavier service to effect market-wide changes in US short-term rates by producing scarcity of funds in the markets [2]. See Figure 3 below. 
Figure 3: Interest Rate on Excess Reserves (orange), 3-Month Commercial Paper Rate (gray) and 3-Month T-Bill Rate (blue)

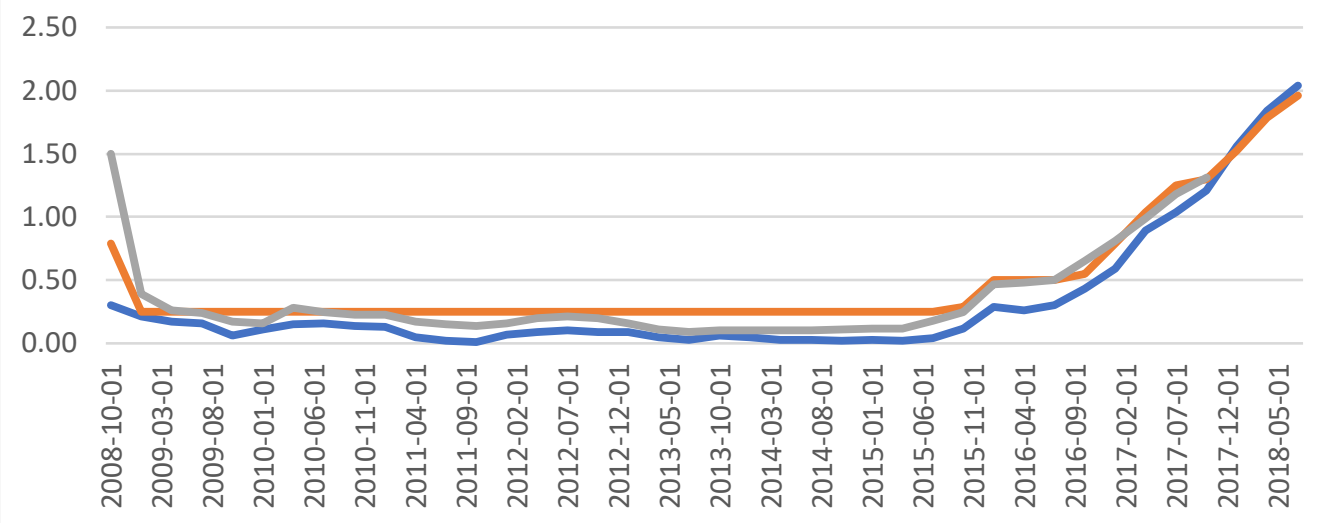

As the amount of excess reserves at the end of 201803 was $\$ 1.8$ trillion and the interest rate on excess reserves was 1.96 percent, the banks were being paid at a $\$ 35$ billion annual rate not to lend on those reserves. Presumably the reason the Fed is not using the traditional method of raising short rates-by expelling excess reserves - is that the quality of the assets that would have to be returned to the banks' balance sheets is sufficiently troublesome that the Fed, owned by the banks, deemed it not worth the risk to the "systemically important financial institutions" that comprise the bulk of the banks taking advantage of the Fed's offer. As the Federal Reserve is obligated to turn over any surplus at the end of its fiscal year to the Treasury, the interest paid on excess reserves appears to be a cost borne by US taxpayers. The reduction of excess reserves required to produce the recent interest rate increases would have been about $\$ 2$ trillion, while excess reserves have come down somewhat less than $\$ 700$ billion. Both effects would appear to be in operation; estimation of relative magnitudes is beyond the scope of this note.

\section{$\underline{\text { Discussion }}$}

The purpose of this note is to point out the far-from-equilibrium condition in US short-term markets resulting from the Fed's recent policy (which is not generally appreciated) and to make a prediction, that the reversal of this disequilibrium is likely to be abrupt. The current monetary strategy resembles a currency peg such as that adopted by the Swiss central bank relative to the Euro in mid-decade that it was forced to abandon abruptly. It is the belief of practitioners that currency pegs universally prove to be unsustainable when global foreign exchange markets move against them. The same result is predicted for the Fed's current interest rate policy. Rates will collapse back to the zero bound with a return to Quantitative Easing as government interest expense rises or the economy enters recession, or both. Or a restructuring of the central banking system will occur that enables banks to shoulder the risks contained in the excess reserves, and the government to fund itself independently of a private financing system that has imposed great costs on the American economy through the GFC and the imbalances of 
$\mathrm{QE}$, not the least of which is the obliteration of pension fund returns at a demographically particularly inopportune time. A return to QE would wreak further damage on these.

The US monetary situation is similar to that in 1937-38, when the Fed attempted to raise interest rates by expelling excess reserves and was forced by recession to return to the zero bound ( $3 / 8$ percent) until the end of World War II. With global debt-to-GDP in developed nations presently estimated at 390 percent [3] the dangers of deflation would seem to outweigh the risks of inflation. The 2010s resemble the 1930s in their basic depression-like configuration of bad debt impactions in the banking system, high income and wealth inequality, over-extended social welfare systems, and dangerously stagnant economies. Austerity on top of this configuration simply deepens the depression; as Keynes would say, effective demand vanishes. The "solution" adopted to the previous impasse was world war (debt-financed fiscal stimulus accommodated by QE). Proposals for debt-to-equity swaps and injections of sovereign currency issuance, especially in the US, offer alternatives [4], with reflationary efforts targeted at infrastructure and productive capital formation, for example. To attempt debt-financedfiscal-stimulus-accommodated-by-QE-neutralized-by-IOER results in a logical contradiction.

The alternatives need to be made ready as the current far-from-equilibrium situation is predicted to produce abrupt and unexpected changes if it follows the analogue of the currency peg. For a discussion of when a cyclical downturn might precipitate adjustment, see [5].

\section{$\underline{\text { References }}$}

[1] Federal Reserve Bank of St. Louis Economic Data supplied all data in quarterly averages. Retrieved from https://fred.stlouisfed.org/ , accessed November 15, 2018.

[2] Appelbaum, Binyamin. The Fed's Policy Mechanics Retool for a Rise in Interest Rates, New York Times, September 13, 2015, retrieved from https://www.nytimes.com/2015/09/13/business/economy/the-feds-policy-mechanics-retoolfor-a-rise-in-interest-rates.html .

[3] Global debt mountain climbs to record \$237 trillion in 2017. MarketWatch, April 10, 2018. Retrieved from https://www.marketwatch.com/story/global-debt-mountain-climbs-to-record237-trillion-in-2017-2018-04-10, accessed November 15, 2018.

[4] Martin Armstrong has made both suggestions on his blog at https://www.armstrongeconomics.com . Modern Monetary Theory also suggests that sovereign currency issuance occurs when a central bank buys the federal debt of a country; but this may lead to a perpetuation of the problems of $Q E$, its unnaturally low interest rates, asset bubbles, and excessive leverage, and the use of unsustainable methods such as interest on excess reserves to reverse its ill effects.

[5] Middleton, Elliott. The Coming Test of Social Trust in America. Arxiv.org, July 12, 2018. https://arxiv.org/abs/1708.06737. 
